\title{
Synthesis of Micro/nanostructured Carbon from Refined Sugar and its Electrochemical Performance
}

\author{
D. Macías-Ferrer ${ }^{1 *}$, J.A. Melo-Banda ${ }^{1}$, R. Silva-Rodrigo ${ }^{1}$, U. Páramo-García ${ }^{1}$, J.Y. Verde-Gómez ${ }^{2}$, \\ P. Del-Angel-Vicente ${ }^{3}$ \\ ${ }^{1}$ Division of Postgraduate Studies and Research, Technological Institute of Cd. Madero, Cd. Madero, \\ Tamaulipas, 89440, México \\ ${ }^{2}$ Division of Postgraduate Studies and Research, Technological Institute of Cancún, Cancún, Quintana \\ Roo, 77500, México \\ ${ }^{3}$ Laboratory of Characterization of Natural and Synthetic Materials, Mexican Institute of Petroleum, \\ Mexico City, 07730, México \\ *E-mail: maestro_macias@hotmail.com
}

doi: $10.20964 / 2018.01 .65$

Received: 9 September 2017 / Accepted: 16 November 2017 / Published: 16 December 2017

Micro/nano-structured carbon (MNC) was synthetized nanocasting method and anhydrous pyrolysis process at $1000{ }^{\circ} \mathrm{C}$ using refined sugar as carbon precursor and SBA-15 as structure directing agent. SBA-15 was prepared through sol gel using the copolymer triblock non ionic pluronic P-123 as surfactant and tetraethyl orthosilicate as Si precursor. The prepared materials were characterized by means of $\mathrm{N}_{2}$ physisorption, Fourier transform infrared spectroscopy (FTIR), X-ray diffraction (XRD), Raman spectroscopy, scanning electron microscopy (SEM), energy-dispersive X-ray spectroscopy (EDS), high resolution transmission electron microscopy (HRTEM) and cyclic voltammetry (CV). The applied characterization techniques revealed that MNC has a mesoporous and turbostratic structure with rope like morphology composed by a set of carbon nanofibers and carbon nanopipes wrapped by thin graphene layers with large specific surface area $\left(1292 \mathrm{~m}^{2} / \mathrm{g}\right)$ and large pore volume $(1.2 \mathrm{cc} / \mathrm{g})$, so MNC is a promising material for applications in adsorption, energy storage and solar cells, supercapacitor electrodes and electrocatalytic supports.

Keywords: SBA-15, nanocasting, carbon nanopipes, carbon nanofibers, turbostratic carbon

\section{FULL TEXT}

(C) 2018 The Authors. Published by ESG (www.electrochemsci.org). This article is an open access article distributed under the terms and conditions of the Creative Commons Attribution license (http://creativecommons.org/licenses/by/4.0/). 